guidance. $\mathrm{He}$ is also indebted to Prof. D. Ushiba, Asist. Prof. S. Sasaki, Dept. of Bacteriology, Keio University, for their guidance, and to Prof. T. Asai, Dr. M. Amaha, Dept. of Agricultural Chemistry, Univ. of Tokyo, to Prof. H. Kadota, the Research Institute for
Food Science, Kyoto University, for their helpful and kind advice. Thanks are also due to Asist. Prof. H. Yamashita, Dept. of Radiology, Keio University, for his sound advice concerning radio-isotopes.

[Bull. Agr. Chem. Soc. Japan, Vol. 22, No. 4, p. $261 \sim 267,1958]$

\title{
A Study of Ascorbic Acid Synthesis with Green Peas Seedling
}

\author{
By Misako Nakatani \\ Department of Agricultural Chemistry, Faculty of Agriculture, Kyushu University \\ Received February 24, 1958
}

\begin{abstract}
Concerning the metabolic pathways of ascorbic acid synthesis, an attempt was made to prepare a soluble enzyme preparation from green peas seedlings, since Mapson et al. obtained mitochondria from cress seedling which was able to synthesize L-ascorbic acid from sugar derivatives, and also a soluble enzyme preparation which was used with the mitochondria, the reaction mechanisms being informed. By the application of this preparation, though it was crude, the reaction route, which seems to be operated in rats and cress seedling and is not catalized in an appreciable rate with Mapson's preparation, was thus studied; namely the reaction was considered to pass via 2-keto-L-gulonic acid.
\end{abstract}

\section{INTRODUCTION}

In the view of a similar configuration, one of the hexose sugars has long been considered to be a precursor to L-ascorbic acid synthesis in vivo. A number of works suggested the relation to the synthesis of ascorbic acid and hexose sugars in plants and animals. However, none of them indicated the direct pathway. Recently, King et al. in their experiments feeding the labeled glucose to rats have shown that the intact chain of glucose could serve as a precursor for L-ascorbic acid. ${ }^{1,2), 3)}$ Further studies with rats revealed the reaction

1) S. S. Jackel, E. H. Mosbach, J. J. Burns and C. G. King, J. Biol. Chem., 186, 569 (1950).

2) H. H. Horowitz, A. P. Doerohuk and C. G. King, J. Biol. Chem., 199, 193 (1952).

3) H. H. Horowitz and C. G. King, J. Biol. Chem., 200, 125 (1953). to pass from D-glucuronolactone to $\mathrm{L}$-ascorbic acid via L-gulonolactone. ${ }^{4,5)}$ Loewus et al. also observed that labeled D-glucose was converted to L-ascorbic acid without inversion of the carbon chain, when the labeled sugars were injected into ripening strawberries. ${ }^{6}{ }^{3}$

Independently, Mapson et al. observed that D-glyceric acid methyl ester did not increase ascorbic acid formation, though it appeared to be in parallel with ascorbic acid synthesis during cress seedling. ${ }^{\text {? }}$ Extensive studies, concerning the metabolism and a precursor of ascorbic acid with various hexose sugar

\footnotetext{
4) H. H. Horowitz and C. G. King, J. Biol. Chem., 205, 815 (1953).

5) J. Burns and C. Evance, J. Biol. Chem., 223, 897 (1956).

6) F.A. Loewus, R. Jang and C. G. Seegmiller, J. Biol. Chem., 222, 649 (1956).

7) F. A. Isherwood, Y.T. Chen and L. W. Mapson, Bochem. J., 56, 15 (1954).
} 
derivatives, were carried out by these workers, using cress seedling and rats. Among various sugar derivatives, only L-gulono, L-galactono-, and D-glucurono- $\gamma$-lactones and D-galacturonic acid methyl ester were shown to be effective for ascorbic acid synthesis. ${ }^{8,9)}$ The series of reactions thus postulated by them were as follows:

D-glucose $\rightarrow$ D-glucuronic acid $\rightarrow$ L-gulonic acid $\rightarrow$ L-ascorbic acid

D-galactose $\rightarrow$ D-galacturonic acid $\rightarrow$ L-galactonic acid $\rightarrow$ L-ascorbic acid

With the mitochondria and a soluble enzyme of cress seedling, the enzymic conversion in the above reactions was further studied, the mechanism of reaction being informed. ${ }^{102}$ As reaction route ( 1 ) was catalyzed in a negligible extent with their preparation, the study was limited within the reaction of route (2).

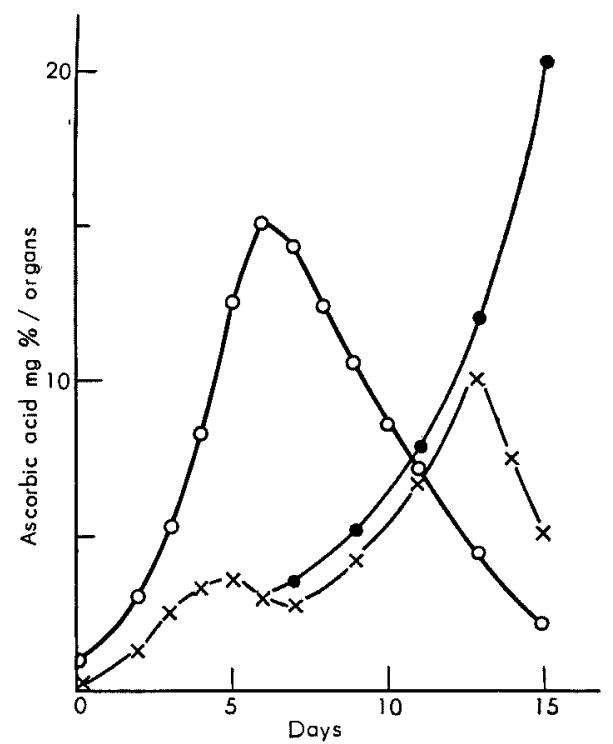

FIG. 1. Ascorbic Acid Contents was Measured in Different Organs During Seedling.

$\mathrm{O}-\mathrm{O}$ : Cotyledon, - Embryo, and $x-x$ : Root.

8) F. A. Isherwood, Y. T. Chen and L. W. Mapson, Biocbem. J., 56, 1 (1954).

9) F. A. Isherwood, Y. T. Chen and L. W. Mapson, Nature, Lond., 171, 348 (1953).

10) L. W. Mapson, F. A. Isherwood and Y. T. Chen, Biochem. $J ., 56,21$ (1954).
For the purpose to study the reaction mechanisms concerning with above routes, the author made an attempt to prepare the soluble enzyme fraction from green peas seedling and studied several properties of this fraction. In the preparation, the activity of crude enzyme was however completely lost during dialysis and the activity was not recovered by the addition of the dialyzed solution. Thus, the mechanisms and properties of overall reactions with crude enzyme solution will be presented in this paper.

\section{EXPERIMENTAL}

Sample. In general, ascorbic acid increases in a large quantity during peas seedling. With green peas, the increment of ascorbic acid contents according to the date of seedling was determined (Fig. 1). When seedling was homogenized and extracted with phosphate buffer, ascorbic acid disappeared. By incubation of this extracted solution at $30^{\circ}$, ascorbic acid gradually reappeared. After certain periods of seedling, cotyledones, embryos and roots of green peas seedlings were separated, and each fraction was homogenized using Potter's homogenizer with $0.1 \mathrm{M}$ phosphate buffer of pH 6.0. The ascorbic acid synthesized after 24 hours" incubation of the solutions was determined and the

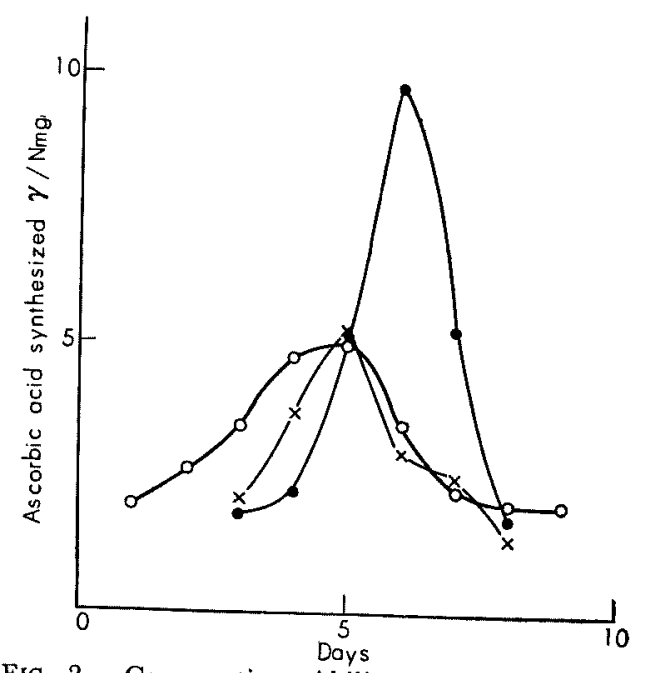

FIG. 2. Comparative Ability of Ascorbic Acid Synthesis with Different Organs of Green Peas Seedling. Activity was Shown According to $\mathrm{N} \mathrm{mg}$. $O$ O: Total peas, -0: embryo, and $x \longrightarrow x$ root. 
results are shown in Fig. 2. Nitrogen was determined by the micro Kjeldahl method.

Preparation. In order to prevent bacterial infection, green peas were immersed in $1 \%$ mercuric dichloride solution for one min., rinsed in running water over night and washed several times with sterilized water. The peas were thus germinated on the sand previously treated with $10 \% \mathrm{HCl}$ and washed thoroughly with sterilized water. Seedling was performed at room temperature in the dark. Since the six-day old embryo was the most active, this was used as an enzyme material. After six days, the peas were collected and washed with distilled water. The embryos were separated from other organs and homogenized with an approximately equal volume of $0.1 \mathrm{M}$ pohsphate buffer of $\mathrm{pH} 6.0$ at $0-5^{\circ}$, using a Werling blender. The homogenate was centrifuged at 12,000 r. p. m. for 20 min. at $0^{\circ}$. The supernatant obtained was used as crude enzyme solution.

Reaction of crude enzyme solution. Two $\mathrm{ml}$. of crude enzyme solution prepared by the above procedure, and $0.5 \mathrm{ml}$. substrate solution were pippeted in a sterilized test tube, and the total volume was made up to $5.0 \mathrm{ml}$. with distilled water. The test tube was cotton stoppered and incubated in a thermostat at $30^{\circ}$. After an appropriate period, $2 \mathrm{ml}$. of $5 \%$ metaphosphate solution was added to the tube, and the ascorbic acid synthesized was determined by Fujita's method, ${ }^{11}$ ) after being titrated with 2,6-dichlorophenolindophenol.

Paper chromatography. Identification of 2, 6-dichlorophenolindophenol reducing substance was tested by paper chromatography according to the method of Chen et al. ${ }^{12}$ A filter paper (Toyo Roshi No. 2 of $30 \times 30 \mathrm{~cm}$ ) was pregnated with $2 \%$ of oxalic acid and dried in air. The sample was developed by twodimensional paper chromatography, treating the solvents of the upper layer of $n$-butanol: aqueous oxalic acid saturated solution $=6: 4\left(20^{\circ} \mathrm{C}\right)$ and the lower layer of phenol : aqueous oxalic acid saturated solution $=5: 1$ $\left(20^{\circ} \mathrm{C}\right)$. After the development at $18^{\circ}$, the paper was dried in air ands preaded with 2,6-dichlorophenolindophenol solution $\left(0.04 \mathrm{~g}\right.$. in 11 . of $\left.0.25 \mathrm{M} \mathrm{Na} \mathrm{NPO}_{4}\right)$. The reducing substance developed a white spot, while the background was colored pink.

The sample was however too dilute to perform paper chromatography directly, condensation being required. After the incubation for 24 hours, the reaction solution

11) A. Fujita, Determination of Vitamins, p. 157 (1946) Seibundo, Tokyö.

12) Y. T. Chen, F. A. Isherwood and L. W. Mapson, Biochem. J., 55, 821 (1953) was spotted at $5 \mathrm{~cm}$. from the bottom of a $30 \times 30 \mathrm{~cm}$. of oxalic acid pregnated filtter paper and the paper was developed with the solvent of $n$-butanol and aqueous saturated oxalic acid solution. Guided by pure ascorbic acid, the fraction was cut and extracted with glass distilled water. With $10 \%$ calcium acetate, the extract was adjusted to $\mathrm{pH} 2$ and then centrifuged. The supernatant was dried over $\mathrm{P}_{2} \mathrm{O}_{5}$ in a vaccum desicator. The concentrated solution was then chromatographed. The 2,6-dichloroindophenol reducing substance was identified as L-ascorbic acid, showing its $R_{F}$ value as 0.28 and 0.41 . By direct condensation of reaction without preliminary treatment of paper chromatography, only one spot was shown which was identified as L-ascorbic acid.

Substrates. D-Gluconic acid was synthesized by Kiliani's method, ${ }^{13)}$ oxidizing D-glucose with brom and D-galacturonic acid was prepared by hydrolyzing pectin with $\mathrm{H}_{2} \mathrm{SO}_{4}$ according to the procedure of Ishikawa. ${ }^{\text {(4) }}$ Diacetone-2-keto-L-gulonic and 2-keto-L-gulonic acids were obtained from Takeda Pharmaceutical Co. by the courtesy of Dr. Sato. D-Glucurono- $\gamma$-lactone was a commercial product obtained from Chugai Pharmaceutical Co. and was used after recrystallization.

\section{RESULTS}

Fractionation. The supernatant $\left(F_{1}\right)$ and the precipitants $\left(\mathrm{F}_{2}\right)$ obtained after centrifuging at 3,000 r.p.m. for $5 \mathrm{~min}$. and the supernatant $\left(\mathrm{F}_{3}\right)$ by second centrifugation of $\mathrm{F}_{1}$ at 12,000 r.p.m. for $20 \mathrm{~min}$. at $0^{\circ}$ were incubated in the above system and ascorbic acid synthesized was estimated. The results are shown in Table I. Fraction 3 which showed the highest activity was thus further studied in regard to

\section{TABLE I}

$\begin{array}{cc}\text { Fraction } & \text { Ascorbic acid } \gamma / \mathrm{ml} \\ 1 & 4.9 \\ 2 & 0.8 \\ 3 & 5.0\end{array}$

Fraction 1: Supernatant of $50 \mathrm{~g}$ embryo extracted solution with equal amount of $0.1 \mathrm{~m}$ phosphate buffer of $\mathrm{pH} 6.0$, after centrifuging at 3,000 r.p.m. for 5 min.

Fraction 2: After centrifuging Fraction 1. at 12,000 r.p.m. for 5 min., the precipitates being suspended with $10 \mathrm{ml}$. of $0.05 \mathrm{M}$ phosphate buffer of $\mathrm{pH} 6.0$.

Eraction 3: The supernatant by the preparation of Fraction 2.

13) H. Kiliani und S. Kleemann, B., 17, 1296 (1884)

14) T. Ishikawa, J. Chen. Soc. Japan, 76, 158 (1955). 


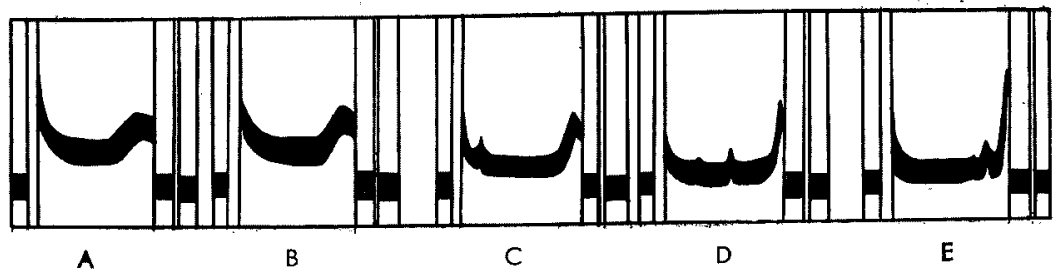

FIG. 3. Ultracentrifuge Diagram of Pea Extract.

A, B, C, D and E show the diagram after constant speed of 42,000 r.p.m. for $8,16,24,32$ and 40 min. at $10^{\circ}$.

its physical properties by ultracentrifugation, using a Spinco Model E. The fraction was centrifuged at 42,000 r.p.m. for 16 min., the results being shown in Fig. 3. Three fractions were observed of which sedimentation constants $\left(\mathrm{s}_{\mathrm{t}}\right.$ ) were 65,41 and, $2.2 \times 10^{-13}$ respectively. For the activity test, $F_{1}$ was thus centrifuged at 42,000 r.p.m., using separation tubes of $1.5 \times 6 \mathrm{~cm}$. After 120 min., the solution was gently pippeted $2.5 \mathrm{ml}$, each from the upper fraction. Each fraction was incubated with D-glucuronolactone and ascorbic acid synthesized was estimated (Table II). The

\section{TABLE II}

ACTIVITY OF FraCtIONS AFTER ULTRACENTRIFUGE

$\begin{array}{cc}\text { Fraction } & \text { Ascorbic acid } \gamma / \mathrm{N} \mathrm{mg} \\ 1 & 1.78 \\ 2 & 1.50 \\ 3 & 1.43 \\ 4 & 0.63\end{array}$

Centrifuge was followed for $120 \mathrm{~min}$, at 42,000 r.p.m. at $0^{\circ} \mathrm{C}$. Each fraction of $2 \mathrm{ml}$. was incubated with $0.5 \mathrm{ml}$. of $1 \%$ glucuronolactone for 24 hrs. at $30^{\circ}$.

Fraction 1: $2.5 \mathrm{ml}$. from the upper layer of a centrifuging tube, $2: 2.5 \mathrm{ml}$. of the second layer, $3: 2.5 \mathrm{ml}$. of the third layer, and 4: the final fraction to the bottom.

third fraction of $\mathrm{s}_{\mathrm{t}}=2.2 \times 10^{-13}$ had the highest activity, thus, the supernatant after the centrifugation at 15,000 r.p.m. for $20 \mathrm{~min}$. was used for the following experiments.

Dialysis of the crude enzyme solution. During dialysis of the crude enzyme solution prepared by the above method, the activity was completely lost. The solution was dialyzed against distilled water, $10 \%, 1 \%$ and $0.1 \%$ of $\mathrm{NaCl}$ aqueous solutions, and phosphate buffers of $0.1 \mathrm{M}$ and $0.05 \mathrm{M}$ of both $\mathrm{pH} 6.0$ and 7.8 at $0^{\circ}$ for 24 hours. The dialyzed solutions lost the activity in every case. To recover the activity, boiled crude enzyme solution, dialyzed outside solution against distilled water and boiled yeast extract solution were added to the reaction system respectively. The activity was however not recovered by any of them. It seemed probable that one or more of the enzymes concerned with the overall reaction would be inactivated during the dialysis and the inactivation would not be due to the loss of coenzymes. Because of the difficulty in purification of this crude enzyme solution, the following experiments were performed with the crude solution, not being purified further.

Optimum pH and temperature. Using D-glucurono-r-lactone as the substrate, the crude enzyme solution was incubated at $30^{\circ}$ for 24 hours with phosphate buffers of $0.05 \mathrm{M}$ by varing their $\mathrm{pH}$ from 5.5 to 7.2. The $\mathrm{pH}$ of solutions was measured by a glass electrode $\mathrm{pH}$ meter. The optimum $\mathrm{pH}$ was shown to be at $\mathrm{pH}$ 5.8-6.2 (Fig. 4). The optimum temperature appeared to be in the range of

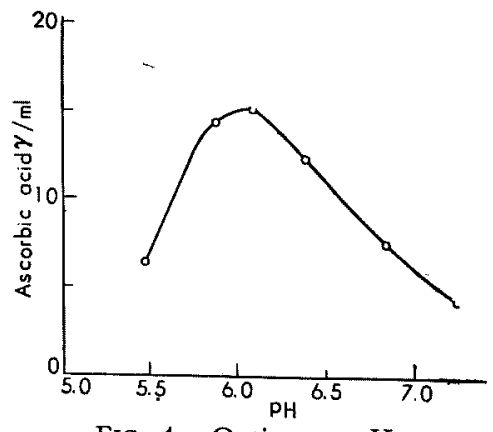

FIG. 4. Optimum $\mathrm{pH}$. 


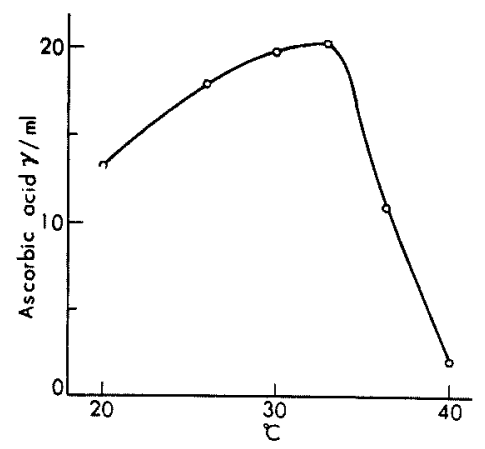

FIG. 5. Optimum Temperature.

$30-33^{\circ}$, the solution being incubated with phosphate buffer of $\mathrm{pH} 6.0$ and $0.05 \mathrm{M}$. By further increment of temperature rapidly reduced activity (Fig. 5).

Progress of the reaction. In the system described above, the enzyme solution was incubated with D-glucurono-r-lactone, at $30^{\circ}$ for periods ranging from 8 to 30 hours. As shown in Fig. 6, the reaction was not in the first-order, but seemed to require some lag phase. If the reaction takes place from glucuronic acid to ascorbic acid through L-gulono$\gamma$-lactone, the results indicated multiple reaction systems. Since the crude enzyme solution was not dialyzed, it contained precursors for ascorbic acid. The overall reactions seemed

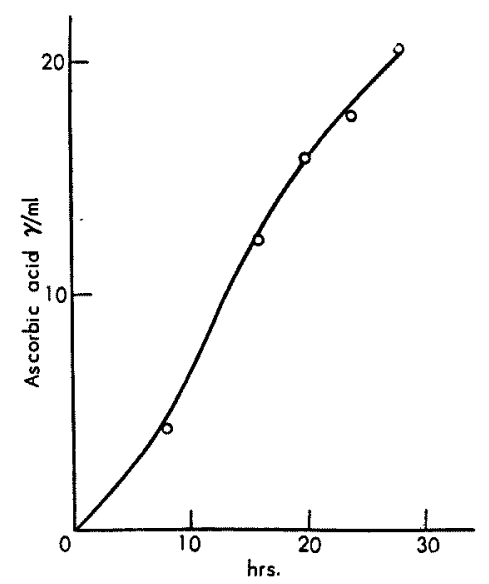

FIG. 6. Reaction proceeding by times.
Table III Effect of Substrates

\begin{tabular}{lrc}
\multicolumn{1}{c}{ Substrate } & Ascorbic & acid $\gamma / \mathrm{ml}$ \\
D-Glucurono- $\gamma$-lactone & 10.25 & 17.04 \\
D-Galacturonic acid & 10.30 & 17.15 \\
D-Gluconic acid & 7.32 & 11.92 \\
D-Galactose & 4.60 & 11.60 \\
D-Glucose & 5.90 & 11.15 \\
Diacetone-2-keto-L-gulonic acid & - & 46.00 \\
2-Keto-L-gulonic acid methyl ester & - & 16.00 \\
Control & 6.95 & 13.56 \\
Enzyme solution was incubated with & $1 \%$ substrates for $24 \mathrm{hrs.}$ \\
at $30^{\circ} \mathrm{C}$.
\end{tabular}

to be limited at some step even in the presence of dializable substances, including precursors.

Substrates. The effects of the substrates are shown in Table III. D-Glucurono-r-lactone and D-galacturonic acid were higher, and Dglucose and D-galactose were lower than the control, while L-gluconic acid was a little effective. Diacetone-2-keto-L-gulonic acid was the most effective substrate, being possibly shown to be a direct precursor with this preparation. 2-Keto-L-gulonic acid methylester was not effective, though it was slightly effective than the control. As a precursor, the free carboxyl group was thus considered to be important. The reaction was probably considered to proceed through 2-keto-L-gulonic acid. For the lower synthetic results with Dglucose and D-galactose, it is considered that these substances are metabolized not only in ascorbic acid synthesis, but also in other reactions which utilize ascorbic acid itself, or require some substances which are necessary for ascorbic acid synthesis.

Inhibitors. The tested reagents were $\mathrm{KCN}$, $\mathrm{NaF}, 2$,4-dinitrophenol, iodoacetate and mercuric chloride of which the results are shown in Table IV. $\mathrm{KCN}$ and $\mathrm{NaF}$ inhibited the reaction at the concentration of $10^{-3} \mathrm{M}$, but only slightly at $10^{-4} \mathrm{M}$. No inhibition by $2,4-$ dinitrophenol was observed, consideration being taken that the reaction may not be related with oxidative phosphorylation, though the enzyme preparation excluded particurates. The group of $\mathrm{SH}$-inhibiting reagents such as 
iodoacetate and heavy metals inhibited the reaction completely, though the heavy metals themselves are oxidizing reagents for ascorbic acid.

\begin{tabular}{lcc}
\multicolumn{1}{c}{ TABLE IV } & EFFECT of INHIBITORS \\
$\quad$ Inhibitor & Conc. & Ascorbic acid $\mathrm{r} / \mathrm{ml}$ \\
$\mathrm{KCN}$ & $10^{-3}(\mathrm{M})$ & 7.8 \\
$\prime \prime$ & $10^{-4}$ & 10.3 \\
$\mathrm{NaF}$ & $10^{-3}$ & 8.4 \\
$\prime \prime$ & $10^{-4}$ & 9.5 \\
$2,4-D i n i t r o p h e n o l$ & $10^{-4}$ & 10.5 \\
Iodoacetate & $10^{-4}$ & 0 \\
$\mathrm{CuCl}_{2}$ & $10^{-4}$ & 0 \\
$\mathrm{HgCl}_{2}$ & $10^{-4}$ & 0 \\
$\mathrm{Control}^{\prime 4}$ & - & 10.5
\end{tabular}

Heat stability. After heating the enzyme solution at $50^{\circ}$, for $30 \mathrm{sec}$. and $1 \mathrm{~min}$., and at $100^{\circ}$ for $30 \mathrm{sec}$, the solution was incubated with D-glucurono- $\gamma$-lactone for 24 hours. The ascorbic acid synthesized was estimated respectively (Table V). At $50^{\circ}$ the enzyme was relatively stable, while at $100^{\circ}$ activity rapidly disappeared.

\begin{tabular}{|c|c|c|}
\hline $\begin{array}{c}\text { Temp. }\left({ }^{\circ} \mathrm{C}\right) \\
50\end{array}$ & $\begin{array}{c}\text { Time }(\min .) \\
0.5\end{array}$ & $\begin{array}{c}\text { Ascorbic acid } \gamma / \mathrm{ml} \\
16.9\end{array}$ \\
\hline 50 & 1.0 & 14.2 \\
\hline 50 & 2.0 & 13.6 \\
\hline 100 & 0.5 & 0 \\
\hline Control & - & 17.0 \\
\hline
\end{tabular}

\section{DISCUSSION}

With crude enzyme solution, L-ascorbic acid could be synthesized from D-galacturonic acid, D-glucurono- $\gamma$-lactone, and diacetone-2-keto-Lgulonic acid which had the highest effect. This enzyme preparation was thus considered to be capable of catalyzing the reaction from D-glucurono- $\gamma$-lactone to L-ascorbic acid through L-gulonic acid, while Mapson's soluble enzyme preparation appeared to be highly effective to the other reaction, that is the reaction from $\mathrm{D}$-galacturonic acid through Lgalactonic acid to $\mathrm{L}$-ascorbic acid.

By Mapson and Breslow, ${ }^{15}$ ) an enzyme which

15) L. W. Mapson and E. Breslow, Biochem. J., 65,30 p (1957). specifically catalyzes the oxidative reaction from L-galactono- $\gamma$-lactone to L-ascorbic acid was partially purified from an acetone powder extract of cauliflower mitochondria, and the reaction route (2) has been confirmed by soluble enzyme system. However, the preparation used in this experiment was considered to catalyze as follows:

D-glucuronic acid $\rightarrow$ L-gulonic acid $\rightarrow$ 2-keto-L-gulonic acid $\rightarrow$ L$\uparrow \quad$ ascorbic acid Diacetone-2-keto-L-gulonic acid

The preparation excluded any particles and dinitrophenol showed no effect to ascorbic acid synthesis, thus, the oxidative phosphorylation coupling reaction seems to be unrelated in overall reactions.

Hence, 2-keto-L-gulonic acid methyl ester was not effective, free carboxyl group is thus considered to be required.

By dialysis, the activity was completely lost irreversibly and activity was not generated, even with the addition of boiled yeast extract and boiled solution of pea extract. Since the dialyzed solution was not tested with 2-ketoL-gulonic acid, it is not to be discussed here whether the loss of activity is due to coenzymes or disintegration of enzyme systems. This problem will be further studied, using a substrate such as 2-keto-L-gulonic acid with this preparation, limiting the reaction within a simple step.

\section{SUMMARY}

The soluble enzyme preparation which can synthesize L-ascorbic acid from D-glucuronic acid, D-galacturonic acid and diacetone-2-ketoL-gulonic acid was obtained from green peas seedling. During dialysis of this preparation, a loss of activity was however caused and it was irreversibly generated by any addition of the dialyzed solution, boiled enzyme solution and boiled yeast extract. The experiments were carried out without dialysis and further purification. The active fraction showed its 
sedimentation constant as $\mathrm{s}_{\mathrm{t}}=2.2 \times 10^{-13}$, indicating a relatively lower molecular weight of protein.

The optimum $\mathrm{pH}$ and temperature of the soluble enzyme was $\mathrm{pH} 5.8-6.2$ and $33^{\circ}$ respectively. The enzyme was relatively stable at $50^{\circ}$ for a short period of heating, but was rapidly inactivated at $100^{\circ}$ Inhibition was observed with iodoacetate, $\mathrm{CuCl}_{2}$ and $\mathrm{HgCl}_{2}$;
$\mathrm{KGN}$ and also $\mathrm{NaF}$ slightly inhibited at $10^{-3} \mathrm{M}$, while 2,4-dinitrophenol showed no inhibition to this preparation.

Acknowledgement. The author is grateful to Prof. Y. Oshima for his valuable advice, and to $\mathrm{Mr}$. and Mrs. Hayashi for their generous assistance in performing ultracentrifuge analysis. 